\title{
The Influence of Product Quality, Service Quality, and Location on Loyalty Customers of Lontong Balap Pak Gendut Surabaya
}

\author{
Angga Widi Kristianto and Agus Baktiono \\ Universitas Narotama Indonesia, J1. Arif Rahman Hakim No.51, Klampis Ngasem, Sukolilo, \\ Surabaya, Jawa Timur 60117 \\ febriwidi3@gmail.com1, agusbhaktiono@narotama.ac.id2
}

\begin{abstract}
Customer loyalty is an important key to maintaining the position of the company in the market and creating efficiency and effectiveness of the company because if the company does not build customer loyalty then the possibility of companies having to spend more and more energy to find new customers Therefore this study aims to analyze whether product quality, service quality, and location can affect customer loyalty to make repurchases at that place. This research is quantitative research and multiple linear regression analysis with a sample of 160 respondents. Furthermore, there are four variables used in this study, namely product quality (X1), service quality (X2), location (X3), and customer loyalty (Y). Data collection was obtained from the distribution of questionnaires to customers of Lontong balap mr.Gendut at Surabaya. The results show that product quality variables (X1), service quality (X2), and location (X3) simultaneously have a significant effect on customer loyalty $(\mathrm{Y})$. Then variable product quality $(\mathrm{X} 1)$, service quality $(\mathrm{X} 2)$, and location $(\mathrm{X} 3)$ partially have a significant effect on customer loyalty (Y). Based on the results of this study, business owners of Lontong Balap should maintain product quality, service quality and location placement so that customers remain and always buy at that pleace.
\end{abstract}

Keyword:

Quality product, quality service, location, loyalty costumers.

\section{Introduction}

The developments that occur in Surabaya always increase from time to time. As a city of heroes and a culinary city that has a lot of diversity, it encourages entrepreneurs to open businesses in Surabaya. This can be seen from the number of businesses that have sprung up at this time, such as the construction of transportation, hotels, new culinary places, and other industrial industries. One of the developments that caught my attention was in the culinary field.

The culinary development in Surabaya is increasing rapidly. This can be seen from the many culinary places in almost every corner of the city of Surabaya. Just like Lontong Balap pak Gendut, which is almost in every corner of this hero city.

Customer loyalty can be created from several factors. Product quality, service quality, and location are expected to affect customer loyalty. A product that will be received by consumers and survive in the market competition is a product that provides satisfaction. Products, services, and locations that are marketed will determine the attitude of consumers to buy, decide at the same time give an impression on the product because there is an assumption that satisfied customers will tend to be more loyal to the product.

Seeing the above phenomenon, I, as a final year student at Narotama University, intends to research with the title The Influence Of Product Quality, Service Quality, And Location On Loyalty Customers Of Lontong Balap Pak Gendut.

Research Objective

1) To analyze the positive and significant influence of product quality on customer loyalty of Lontong Balap pak Gendut at Surabaya.

2) To analyze the positive and significant influence of service quality on customer loyalty of Lontong Balap pak Gendut at Surabaya. 


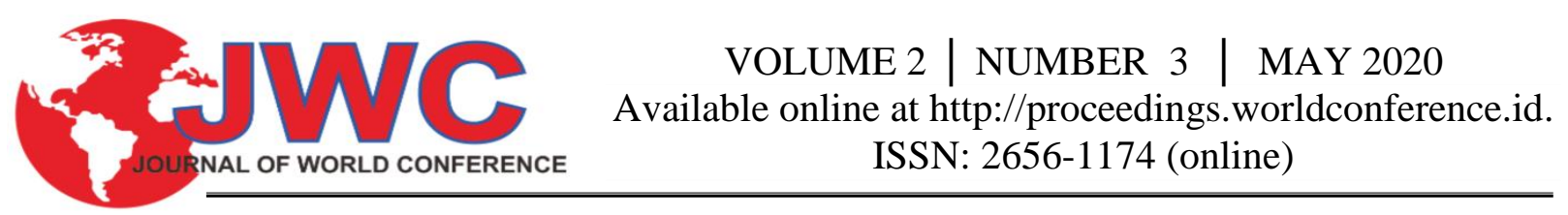

3) To analyze the positive and significant influence of location on customer loyalty of Lontong Balap pak Gendut at Surabaya.

4) To analyze the positive and significant influence of product quality, service quality and location on customer loyalty of Lontong Balap pak Gendut at Surabaya.

\section{Literature Review}

\subsection{Product Quality}

Product quality is the product offered by the seller so that it has more selling value that is not owned by the competitor's product. According to Kotler and Keller (2009), product quality is the totality of features and characteristics of a product or service that depends on its ability to satisfy the stated or implied.

\subsection{Service Quality}

Supranto (1980) service quality is a result that must be achieved and carried out with action. But these actions are intangible and easily lost, but can be felt and remembered, the impact is that consumers can be more active in the process of consuming products and services of a company.

\subsection{Location}

Tjiptono (2015) location refers to various company activities that seek to facilitate and facilitate the delivery or distribution of goods and services from producers to consumers. Whereas according to Kotler and Amsntrong (2014) "place include company activities that make the product affordable to target consumers" and according to Lupiyoadi and Hamdani (2011) location is a decision made by the company or educational institution concerning where its operations and staff are placed.

\subsection{Loyalty Customers}

Customer loyalty is a repeat purchase carried out by a customer because of a commitment to a brand or company Philip Kotler (2005).

\subsection{Previews Research.}

Perception of product quality, price, promotion, and location does not have a simultaneous effect on customer loyalty. Research conducted by Agustin, (2018) with the title "The Effect of Product Quality, Service Quality, and Brand Image on Customer Loyalty in Jawa Pos Radar Kediri Newspaper" The purpose of this study was to determine the effect of product quality, service quality, and brand image on loyalty Java newspaper customers radar post in Kediri.The research method used is a sample and a quantitative approach. The results showed that product quality has an effect on customer loyalty, and service quality and brand image variables have a significant effect on customer loyalty.itment to a brand or company Philip Kotler (2005).

\subsection{Conceptual Framework}

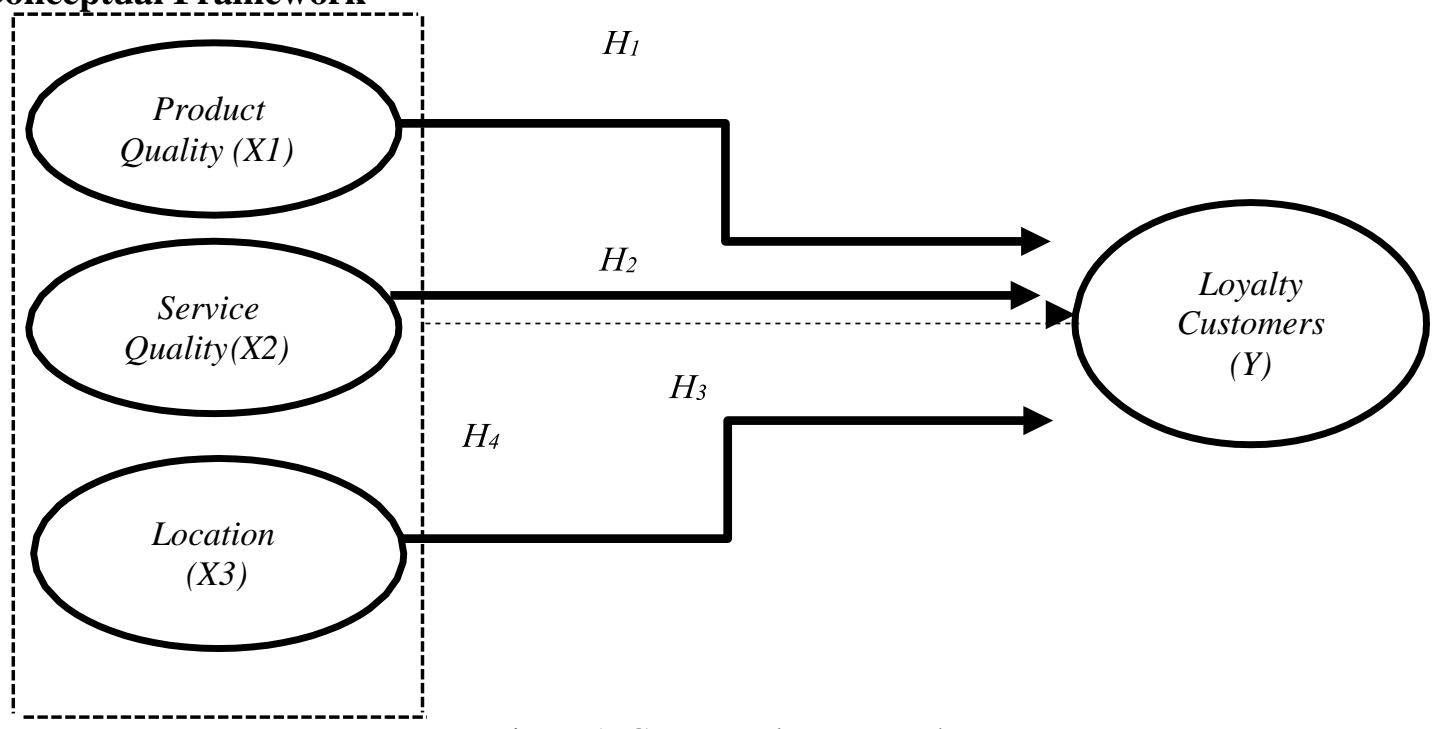

Figure 1. Conceptual Framework

\subsection{Hypothesis}

H1: product quality has a positive and significant effect on loyalty customers 


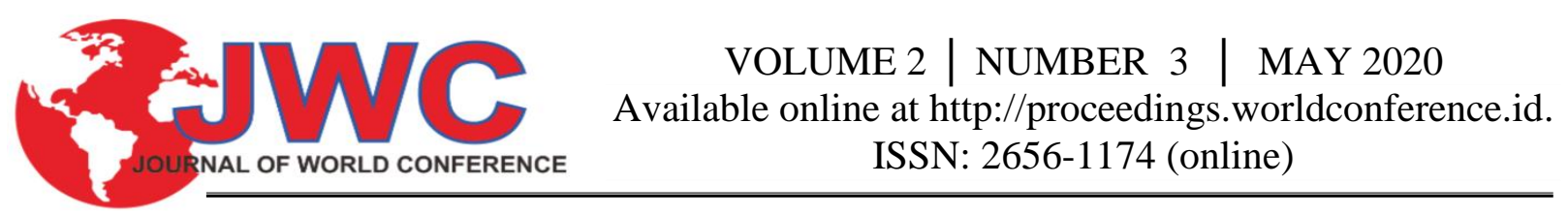

H2: service quality has a positive and significant effect on loyalty customers

H3: location has a positive and significant effect on loyalty customers

H4: product quality, service quality, location has a positive and significant effect on loyalty customers

\section{Research Methods}

\subsection{Types of research}

This research approach uses a quantitative approach. According to Sugiyono (2013) quantitative method is a study that uses samples and numerical data or data in the form of numbers to examine certain populations or samples, sampling techniques are generally done randomly, data collection uses research instruments, quantitative / statistical analysis with the aim to test what has been set.

\subsection{Population and Samples}

Population is a generalization area consisting of: objects / subjects that have certain qualities and characteristics set by the researcher to be studied and then conclusions drawn (Sugiyono, 2013). The population in this study are consumers of Lontong Balap pak Gendut at Surabaya whose numbers are unknown because they do not have customer data records.

Sugiyono (2013) says the sample is part of the number and characteristics of the population that is considered to be able to inherit the population. The method in this study uses non probability sampling with accidental sampling technique that is the sampling method that is done by using anyone who was met by chance as a sample means that whoever happens to meet the researcher can be used as a sample, if the person views the criteria accordingly and suitable to be used as a data source (Sugiyono, 2013). Because the population size is unknown for determining the number of samples to be used in this study will use a formula based on Hair (2014) whose sample size depends on the number of all indicators $16 \times 10=160$. Data collection is done by distributing questionnaires. The sample at Lontong Balap pak Gendut at Surabaya : Lontong Balap pak Gendut at Jl. Mayjen Prof. Dr. Moestopo No.11, Pacar keling, Lontong Balap pak Gendut at Jl. Kranggan No.60, Sawahan, Lontong Balap pak Gendut at Jl. Embong malang No.38,Surabaya. The observation strat from Oktober 2019 - Desember 2019.

\subsection{Data Analysis Techniques}

In this study using multiple linear regression analysis to determine how much influence the independent variable (independent) on the dependent variable (dependent) on changes from each increase or decrease in the independent variable that will affect the dependent variable (Sugiyono, 2013). Multiple linear regression analysis is used to analyze the influence of independent variables (product quality, service quality, location) on the dependent variable, namely loyalty customers.

The mathematical formulas of multiple linear regressions used in this study are:

$\mathrm{Y}=\mathrm{a}+\mathrm{b} 1 \mathrm{X} 1+\mathrm{b} 2 \mathrm{X} 2+\mathrm{b} 3 \mathrm{X} 3+\mathrm{e}$

Description :

Y= Loyalty Customers

$\mathrm{a}=$ Constant

$\mathrm{b} 1, \mathrm{~b} 2, \mathrm{~b} 3=$ Regression coefficient

$\mathrm{x} 1=$ Product Quality

$\mathrm{x} 2=$ Service Quality

$\mathrm{x} 3=$ Location

$\mathrm{e}=$ error disturbances

\subsection{Reliability and Validity test}

Reliability shows consistency and stability of a score (scale of measurement). An instrument is declared reliable if the reliability coefficient is at least 0.6 Arikunto (2013). An instrument is said to be valid if it is able to uncover data from variables that are properly examined. Usually the minimum requirement to be considered fulfilling the requirements is if rcount> rtable(Ghozali, 2005).

Correlation Coefficient (R) and Determination Coefficient (R2)

Correlation coefficient $(\mathrm{R})$ is used to determine the relationship between independent variables $(\mathrm{X})$ to the dependent variable (Y) together. The coefficient of determination (R2) basically measures how far the ability of the model in explaining variations in independent variables (Ghozali, 2005).

\subsection{Hypothesis Testing}

1. Test F To find out whether the independent variable has a significant effect or not on the dependent variable.

2. Test t To see whether the independent variable partially affects the dependent variable. 


\subsection{Classical Assumption Test}

1. Multicollinearity Test, Testing this assumption to show the existence of a linear relationship between the independent variables in the regression model and to show the presence or absence of a high degree of colinearity among the independent variables.

2. Heterocedasticity Test, This test aims to find out whether in the regression model variance inequalities occur from one residual to another observation.

3. Normality Test, This test is conducted to see whether the residual or residual variable regression model has a normal distribution or not

\section{Result and Discussion}

\subsection{Reliability Test}

Table 1. Test Result Reliability

\begin{tabular}{ll} 
Cronbach's Alpha & N of Items \\
\hline 0.905 & 16 \\
\hline & Source: SPSS Output Data
\end{tabular}

The data of this study have cronbach's alpha 0.905 and are above 0.60 , so the data of this study can be declared reliable and reliable.

\subsection{Validity Test}

Table 2. Test Result Validity

\begin{tabular}{|c|c|c|c|c|}
\hline No. & Indikator/Variabel & Korelasi & r Tabel & Explanation \\
\hline & Product Quality & & & \\
\hline 1. & $\mathrm{X} 2.1$ & 0,546 & 0,1305 & Valid \\
\hline 2. & X2.2 & 0,658 & 0,1305 & Valid \\
\hline \multirow[t]{2}{*}{3.} & $\mathrm{X} 2.3$ & 0,518 & 0,1305 & Valid \\
\hline & Service Quality & & & \\
\hline 1. & $\mathrm{X} 4.1$ & 0,635 & 0,1305 & Valid \\
\hline 2. & $\mathrm{X} 4.2$ & 0,548 & 0,1305 & Valid \\
\hline 3. & X4.3 & 0,54 & 0,1305 & Valid \\
\hline 4. & X4.4 & 0,531 & 0,1305 & Valid \\
\hline \multirow[t]{2}{*}{5.} & $\mathrm{X} 4.5$ & 0,471 & 0,1305 & Valid \\
\hline & Location & & & \\
\hline 1. & X1.1 & 0,57 & 0,1305 & Valid \\
\hline 2. & X1.2 & 0,631 & 0,1305 & Valid \\
\hline 3. & X1.3 & 0,633 & 0,1305 & Valid \\
\hline \multirow[t]{2}{*}{4.} & $\mathrm{X} 1.4$ & 0,639 & 0,1305 & Valid \\
\hline & Loyalty Customers & & & \\
\hline 1. & Y.1 & 0,534 & 0,1305 & Valid \\
\hline 2. & Y.2 & 0,624 & 0,1305 & Valid \\
\hline 3. & Y.3 & 0,66 & 0,1305 & Valid \\
\hline 4. & Y.4 & 0,527 & 0,1305 & Valid \\
\hline
\end{tabular}

Source: SPSS Output Data processed

The results showed that all indicators used to measure the variable product quality (X1), service quality (X2), location (X3), and loyalty costumers $(\mathrm{Y})$ used in this study had correlation coefficients or $\mathrm{r}_{\text {counts }}$ greater than rable $=$ $0.1305\left(\mathrm{r}_{\text {table }}\right.$ value for $\left.n=160\right)$. So that all these indicators are valid. 


\subsection{Correlation Coefficient $(\mathbf{R})$ and Determination Coefficient $\left(\mathbf{R}^{2}\right)$}

Table 3. Test Results Determination Coefficient Model

Summary

\begin{tabular}{ll|l|l|l}
\multicolumn{4}{c}{ Model Summary $^{b}$} \\
\hline Model & R & R Square & Adjusted R Square & Std. Error of the Estimate \\
\hline 1 & $.688^{\mathrm{a}}$ & .474 & .464 & 2.001 \\
\hline
\end{tabular}

a. Predictors: (Constant), TOTAL_X3, TOTAL_X2,TOTAL_X1

b. Dependent Variable:TOTAL_Y

Source: SPSS Output Data

The coefficient value is $\mathrm{R}>0.5$ which is equal to 0.688 . This means that the variables of product quality (X1), service quality (X2), and location (X3), have a significant effect on loyalty costumers (Y). Adjusted R Square results are 0.464 which indicates that the variable product quality (X1), service quality (X2), location (X3), has an effect of $46.4 \%$ on loyalty costumers (Y). And the remaining $53.6 \%$ is influenced by other variables not examined in this study.

\subsection{Multiple Regression Linier}

Table 4. Result Multiple Regression Linier

\begin{tabular}{lcccc}
\hline \multicolumn{1}{c}{ Keterangan } & $\mathrm{B}$ & $\mathrm{t}$ hitung & $\mathrm{t}$ tabel & Sig \\
\hline Konstanta & 1,004 & & & \\
Product Quality & 0,213 & 3.032 & 1,975 & 0,003 \\
Service Quality & 0,153 & 2.097 & 1,975 & 0,038 \\
Location & 0,437 & 5.737 & 1,975 & 0,000 \\
R & & & & 0,688 \\
Rsquare & & & 0,474 \\
R adjusted & & & 0,464 \\
F hitung & & & 46,845 \\
F tabel Sig & & & 2,004 \\
Df & & & 0,000 \\
SE & & & 0,500 \\
E & & & \\
\hline
\end{tabular}

Source: Author (2019)

Regression equation models that can be written from these results in the form of standard form regression equations are as follows :

$\mathrm{YR}=1,004+0,213 \mathrm{X} 1+0,153 \mathrm{X} 2+0,437 \mathrm{X} 3$ e YRmax $=0,98750,213 \mathrm{X} 1+0,153 \mathrm{X} 2+0,437 \mathrm{X} 3 \mathrm{YRmin}=$ $0,213 \mathrm{X} 1+0,153 \mathrm{X} 2+0,437 \mathrm{X} 3-0,9875$

\subsection{Hypothesis test}

\section{F Test (Simultant)}

Table 5. F Result Test (simultan)

\begin{tabular}{|c|c|c|c|c|c|c|}
\hline Model & & $\begin{array}{l}\text { Sum of } \\
\text { Squares }\end{array}$ & df & Mean Square & $\mathrm{F}$ & Sig. \\
\hline \multirow[t]{3}{*}{1} & Regression & 562.641 & 3 & 187.547 & 46.845 & $.000^{\mathrm{b}}$ \\
\hline & Residual & 624.552 & 156 & 4.004 & & \\
\hline & Total & 1187.194 & 159 & & & \\
\hline
\end{tabular}


Based on the data in table 5 above it is known that obtained Fcount $=46.845$. while the Ftable value is obtained at 2.66. And a significant value of $0,000<0.05$ so that it can be concluded Product Quality (X1), Service Quality (X2) and Locatiom (X3) simultaneously have a positive and significant effect on Loyalty Customers (Y) Lontong Balap pak Gendut at Surabaya.

\section{T Test (Partial)}

Table 6. T Result Test (Partial)

\begin{tabular}{|c|c|c|c|c|c|c|}
\hline \multirow[b]{2}{*}{ Model } & & \multirow{2}{*}{\multicolumn{2}{|c|}{ Unstandardized Coefficients }} & \multicolumn{3}{|l|}{ Standardized } \\
\hline & & & & $\begin{array}{l}\text { Coefficients } \\
\text { Beta }\end{array}$ & $\mathrm{t}$ & Sig. \\
\hline \multirow[t]{4}{*}{1} & (Constant) & 4.014 & .893 & & 4.496 & .000 \\
\hline & TOTAL_X1 & .284 & .094 & .224 & 3.032 & .003 \\
\hline & TOTAL_X2 & .123 & .058 & .150 & 2.097 & .038 \\
\hline & TOTAL_X3 & .437 & .076 & .433 & 5.737 & .000 \\
\hline
\end{tabular}

Source: SPSS Output Data

Based on table 6 above it is known that the value tcount variable product quality (X1) is 3.032, the service quality variable (X2) is 2.097 and the variable loyalty costumers (X3) is 5.737.

\subsection{Classical Assumption test 1. Multikolinearity}

Table 7. Multicollinearity Test Results

\begin{tabular}{llll}
\hline & & Tolerance & VIF \\
\hline 1 & TOTAL_X1 & .618 & 1.619 \\
& TOTAL_X2 & .658 & 1.520 \\
& TOTAL_X3 & .593 & 1.687 \\
\hline
\end{tabular}

Source: SPSS Output Data

Based on table 7 it can be seen that the regression model does not experience multicollinearity problems. This can be seen in the tolerance value of each independent variable greater than 0.1. The VIF calculation results also show that the VIF value of each independent variable is less than 10.

\section{Heteroskedastisity}

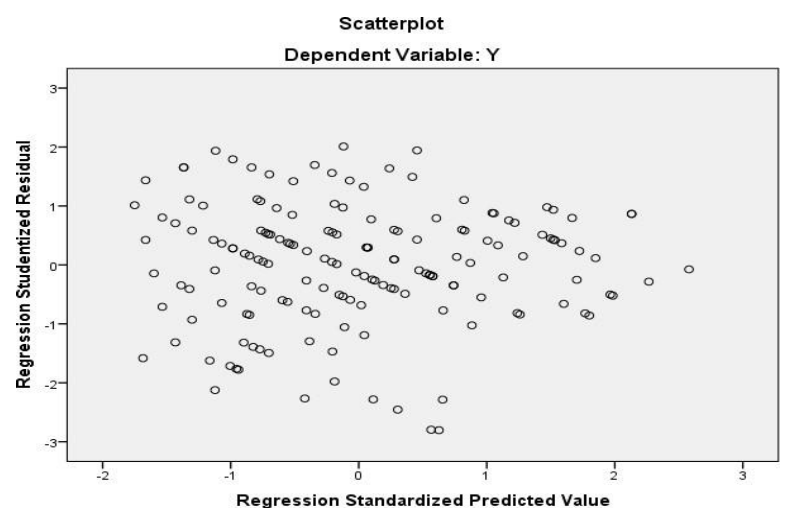

Source: SPSS Output Data

Figure 2. Heteroskedastisity Result

From the Scatterplot graph in Figure 2 it can be seen that the points spread randomly, both above and below the zero on the $\mathrm{Y}$ axis. It can be concluded that the model in this study fullfills the requirements of homoskedasticity or does not occur symptoms of heteroscedasticity. 


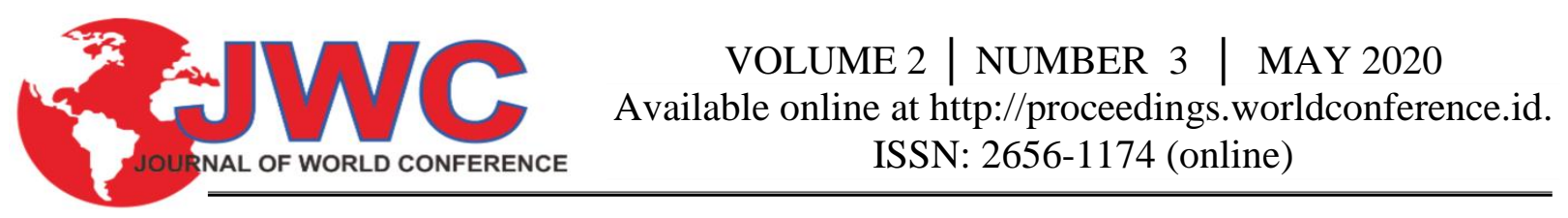

\section{Normality}

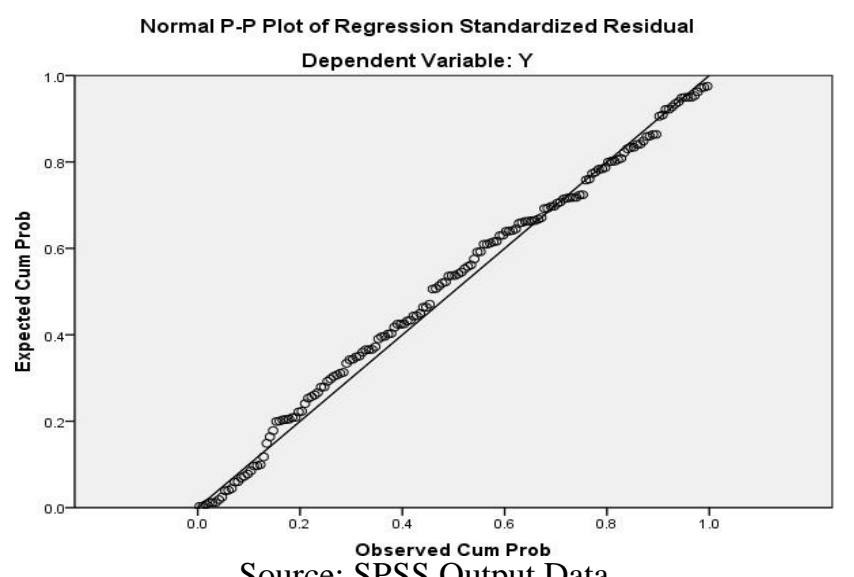

Source: SPSS Output Data

Figure 3. Normality result

In figure 3 it can be seen that the standardized normal probability plot of regression graph shows a normal graph pattern. This can be seen from the points that spread around the diagonal line and the diagonal line from the lower left to the top right. Then it can be concluded that the regression model is feasible because it meets the assumptions of normality.

\subsection{Discussion}

\section{1) Effect of Product Quality towards Loyalty Customers}

Based on the test results obtained by the value of tcount for the Product Quality variable on Loyalty Customers shows the value of tcount $=3.032>$ from ttable 1.975 with a significance of $0.003<0.05$ meaning significant. Thus the H1 hypothesis in this study is accepted, this shows that one's Product Quality can influence consumer Loyalty Costumers Lontong Balap pak Gendut at Surabaya.

\section{2) Effect of Service Quality towards Loyalty Customers}

Based on the test results obtained by the value of tcount for the Service Quality variable on Loyalty Customers shows the value of $\mathrm{t}$ count $=2.097>$ of ttable 1.975 with a significance of $0.038<0.05$ means significant. Thus the H2 hypothesis in this study is accepted, this shows that Service Quality has a significant effect on Loyalty Customers Lontong Balap pak Gendut at Surabaya.

\section{3) Effect of Location towards Loyalty Customers}

Based on the test results obtained the value of tcount for the Location variable on Loyalty Costumers shows the value of tcount $=5,737>$ from ttable 1.975 with a significance of $0.00<0.05$ meaning significant. Thus the H3 hypothesis in this study is accepted, this shows that Location has a significant effect on Loyalty Costumers Lontong Balap pak Gendut at the Surabaya

\section{4) Effect of Product Quality, Service Quality, Location towards Loyalty Customers Lontong Balap pak Gendut at Surabaya \\ Based on the results of simultaneous hypothesis testing (Test F) of independent variables (free), Product Quality, Service Quality and Location simultaneously affect the dependent variable (Loyalty Customers). This is evidenced from the significance value of 0.000 or less than 0.05 and Fcount $=46.845$ while the Ftable value is obtained at 2.66. Thus Fcount 46.845> Ftable 2.66.}




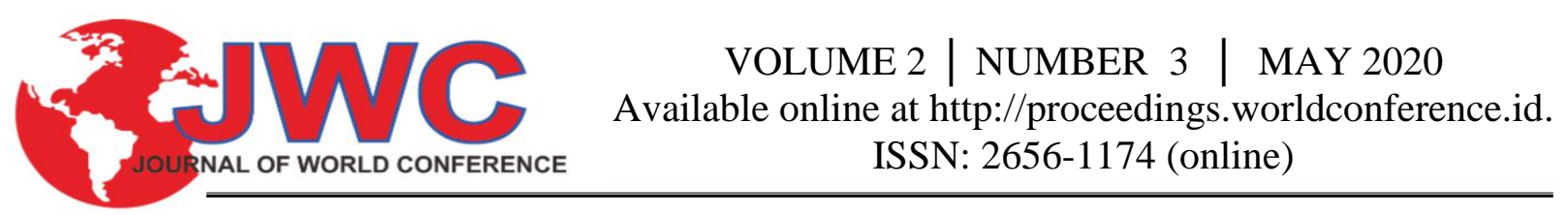

\section{Conclussion} as follows:

There are four constructive findings that can be concluded from the overall research results, which are listed

1) Product Quality have significant influences to the Loyalty Customers Lontong Balap pak Gendut get results in product quality indicators.

2) Service Quality has a significant influence on the Loyalty Costumers Lontong Balap pak Gendut get results in service quality indicators.

3) Location significant influence on Loyalty Costumers Lontong Balap pak Gendut get result in location indicator.

4) Based on the results of simultaneous hypothesis testing (Test F) of independent variables (free), Product Quality, Service Quality and Location simultaneously affect the dependent variable (Loyalty Customers). This is evidenced from the significance value of 0.000 or less than 0.05 and Fcount $=46.845$ while the Ftable value is obtained at 2.66. Thus Fcount 46.845> Ftable 2.66.

\section{References}

Agustin, C. I. (2018). Jurnal Jawa Pos Radar Kediri Oleh : Choirina Ika Agustin Dibimbing Oleh : Surat Pernyataan Artikel Skripsi Tahun 2018. Produk, Pengaruh Kualitas Pelayanan, Kualitas, 02(03).

Arief, M., Azis, E., Manajemen, P., Telekomunikasi, B., \& Ekonomi, F. (2017). No Title, 4(3), 2382-2392.

Ghozali, I. (2005). Aplikasi Analisis Multivariate Dengan Program SPSS. Semarang: Badan Penerbit Universitas Diponegoro.

Hair, J. F. (2014). PLS-SEM: Indeed A Silver Bullet. PLS-SEM: Indeed A Silver Bullet (January 2015), 37-41.

Halim, P., Swasto, B., Hamid, D., \& Firdaus, M. R. (2014). The Influence Of Product Quality, Brand Image , And Quality Of Service To Customer Trust And Implication On Customer Loyalty ( Survey On Customer Brand Sharp Electronics Product At The South Kalimantan Province ), 6(29), 159-166.

Kotler, P. (2000). Manajemen Pemasaran Edisi Millenium. Jakarta: Indeks.

Kotler, P. (2005). Manajemen Pemasaran. Jakarta: PT. Indeks Kelompok Gramedia. Marina, S., \& Darmawati, A. (2014). Pengaruh Kualitas Pelayanan Terhadap Loyalitas Pelanggan Pada Perusahaan Penerbangan Full Service Airlines The Effect Of Service Quality On Customers Loyalty In Full Service Airlines, 01(02), 157164.

Minar, D. (2017). Brand Image And Product Quality On Customer Loyalty ( Survey In Cekeran Midun ), 16(1), 4350.

Nuridin. (2018). Effect Of Service Quality And Quality Of Products To Customer Loyalty With Customer Satisfaction As Intervening Variable In PT . Nano Coating Indonesia International Journal Of Business And Applied Social Science ( IJBASS ).

Sundari, M. (2018). Jurnal Wonojoyo Gurah The Influence Of Service Quality, Location, And Price On Customer Loyalty Pharmacy Sagita Farma Wonojoyo Gurah Oleh : Dibimbing Oleh : Program Studi Manajemen Surat Pernyataan Artikel Skripsi Tahun 2018, 02(01), 1-10.

Tjiptono, F. (2005). Strategi Pemasaran. Yogyakarta: Andi Offset. 